\title{
E-Learning Terintegrasi Kearifan Lokal Bali Berbasis 4C pada Mata Pelajaran IPA
}

\section{Putu Oktap Indrawan*, I Gede Jaka Mahendra²}

1,2 Politeknik Ganesha Guru, Bali, Indonesia

\section{ARTICLE INFO}

\section{Article history:}

Received August 22, 2021

Revised August 30, 2021

Accepted September 14, 2021

Available online October 25, 2021

Kata Kunci:

E-Learning, Kearifan Lokal Bali, 4C, Hasil Belajar

Keywords:

E-Learning, Balinese Local Wisdom, 4C, Learning Outcomes

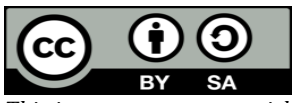

This is an open access article under the $\underline{C C}$ BY-SA license.

Copyright (C) 2021 by Author. Published by Universitas Pendidikan Ganesha.

\begin{abstract}
A B S T R A K
Integrasi kearifan lokal dalam e-learning belum dilakukan secara komprehensif. Tujuan penelitian ini adalah untuk mendesain, melakukan uji coba, dan mengevaluasi hasil implementasi e-learning terintegrasi Kearifan Lokal Bali yang komperehensif berbasis 4C. Jenis penelitian yang dipilih adalah Research and Development $(R \& D)$ prosedur mengikuti Borg dan Gall. Subjek uji coba adalah 66 siswa pada kelas 8A5 dan 8A10 dengan fokus materi "Struktur dan Fungsi Tumbuhan". Metode pengambilan data yang digunakan adalah observasi, wawancara, kuesioner dan tes. Data yang terkumpul akan dianalisis secara kualitatif dengan tehnik analisis Interactive data Analysis Model Miles \& Huberman dan analisis kuantitatif dengan Wilcoxon Signed Rank Tes. Hasil penelitian menunjukkan desain e-learning sudah mengintegrasi kearifan lokal Bali secara komprehensif serta mengembangkan 4C dengan kualitas masuk kualifikasi sangat baik berdasarkan penilain ahli materi dan e-learning. Hasil uji coba e-learning melalui pengujian Wilcoxon Signed Rank Test menunjukkan ada perbedaan signifikan antara data nilai pre-test dan post-test. Evaluasi e-learning melalui respon siswa dan guru berdasarkan CCAF masuk kriteria sangat baik. Peneliti dan guru dapat menggunakan ini sebagai alternatif model dan melakukan eksperimen dengan mempertimbangkan gaya belajar dan pengukuran detail pada 4C pada siswa.
\end{abstract}

\section{A BS TRACT}

The integration of local wisdom in e-learning has not been carried out comprehensively. This study aimed to design, conduct trials, and evaluate the results of implementing comprehensive e-learning integrated Balinese Local Wisdom based on 4C. The type of research chosen is the Research and Development (R\&D) procedure following the Borg and Gall. The test subjects were 66 students in grades $8 A 5$ and 8A10, focusing on the material "Structure and Function of Plants." Data collection methods used were observation, interviews, questionnaires, and tests. The collected data will be analyzed qualitatively using the Miles \& Huberman Interactive data analysis technique and quantitative analysis using the Wilcoxon Signed Rank Test. The study results show that the e-learning design has integrated Balinese local wisdom comprehensively and developed 4Cs with very good quality entry qualifications based on the assessment of material experts and e-learning. The results of the e-learning trial through the Wilcoxon Signed Rank Test showed that there was a significant difference between the pre-test and post-test score data. Evaluation of e-learning through student and teacher responses based on CCAF is very good. Researchers and teachers can use this as an alternative model and conduct experiments by considering learning styles and measuring details on the 4Cs in students.

\section{PENDAHULUAN}

Pembelajaran pada Era Revolusi industry 4.0 (ERI 4.0) digambarkan oleh Dunwil antara lain adanya perubahan tata ruang kelas; lanskap pendidikan mengarah kepada pembelajaran e-learning dan augmented reality; tugas yang lebih fleksibel dan mampu mengakomodasi berbagai jenis gaya belajar siswa; MOOC dan berbagai alternatif e-learning berdampak pada pendidikan menengah (Dunwill, 2016). Pembelajaran daring atau e-learning adalah segala jenis pembelajaran yang melibatkan internet ataupun intranet (Zainul, 2020). Menurut Patrict e-learning didefinisikan sebagai proses pembelajaran yang disampaikan, diaktifkan, dan atau dimediasi teknologi elektronik untuk tujuan pembelajaran tertentu (Wu, 2018). E-learning berdasarkan waktu komunikasi dibagi menjadi dua yaitu synchronous (langsung atau realtime) dan asynchronous (tidak langsung atau tidak bersamaan) (Uskov \& Howlett, 2019). Elearning synchronous memiliki kelebihan: (1) bersifat interktif, siswa dapat melakukan presentasi, diskusi, dan bertukar ide antar siswa atau dengan guru secara langsung; dan (2) tatap layar guru dan siswa secara langsung memotivasi siswa belajar lebih aktif (Mehri \& Uplane, 2015; Weiser et al., 2018). Sedangkan, $e$ learning asynchronous memiliki kelebihan: (1) fleksibilitas artinya siswa dapat belajar kapanpun dan 
dimanapun dengan mengakses e-learning; dan (2) belajar mandiri, maksudnya siswa mengatur sendiri jam belajar dan meninjau materi pembelajaran beberapa kali sebelum mengambil keputusan untuk melanjutkan ke tahap selanjutnya (Barbierato et al., 2021; Mehri \& Uplane, 2015). E-learning dinyatakan mampu meningkatkan prestasi belajar (Mehri \& Uplane, 2015), khusunya prestasi belajar IPA siswa VIII. Beberapa hal yang perlu dipertimbangkan dalam implementasi e-learning: (1) masalah infrastruktur, lingkungan rumah, kendala waktu dan tidak tersedianya sumber daya; (2) fokus tidak hanya pada pembelajaran siswa tetapi juga membantu mereka menjadi pembelajar mandiri; (3) guru harus memberi penjelasan singkat kepada siswa tentang tugas biarkan siswa menyelesaikannya dan kemudian berdiskusi pada sesi sinkron berikutnya; (3) Guru harus dilatih tentang bagaimana menjadi guru daring yang efektif karena diamati bahwa tidak semua guru dapat menangani e-learning; (4) perlu adanya sinergi dengan orang tua untuk membentuk lingkungan belajar yang mendukung anak secara optimal (Jan, 2020). Menyempurnakan pembelajaran e-learning dibutuhkanlah sebuah kolaborasi yang sesuai dengan kebutuhan pembelajaran, salah satu solusi yang digunakan adalah Mengintegrasi kearifan lokal dalam $e$ learning.

Integrasi kearifan lokal ke dalam e-learning dapat dilakukan dengan tiga cara yaitu menjadikan kearifan lokal konten pembelajaran atau sintaks dalam proses pembelajaran (Indrawan et al., 2020). Integrasi kearifan lokal sebagai konten adalah dengan menyisipkan kearifan lokal sebagai bagian dari materi pembelajaran IPA, tentunya kearifan lokal tersebut harus berkaitan dengan materi yang dibahas. Integrasi kearifan lokal sebagai konteks dengan cara menghubungkan kearifan lokal dengan konteks pembelajaran. Konteks tersebut dalam pembelajaran IPA dapat berupa konteks motivasi belajar, karakter bangsa, sikap, pengetahuan, dan atau keterampilan ilmiah. Mengembangkan nilai-nilai karakter berdasarkan Kearifan Lokal Bali dalam Pembelajaran Fisika di SMP (I. Suastra, 2017). Hal tersebut sebagai salah satu contoh integrasi kearifan lokal sebagai konteks dalam pembelajaran karakter. Sedangkan, integrasi Kearifan Lokal Bali sebagai sitaks adalah menjadikan kearifan lokal sebagai langkahlangkah dalam pembelajaran, misalnya menjadikan Tri Kaya Parisudha sebagai sintaks pembelajaran(Indrawan et al., 2019). Berbagai alternatif integrasi Kearifan Lokal Bali ke dalam pembelajaran, khususnya e-learning memberikan peluang penanaman kearifan lokal pada siswa dengan lebih konprehensif. Integrasi Kearifan Lokal Bali ke dalam e-learning menargetkan pengembangan learning and inovation skill atau 4C dalam proses pembelajaran. Learning and inovation skill atau 4C terdiri dari kemampuan: berpikir kritis, kemampuan berpikir kreatif dan inovatif, kemampuan komunikasi, dan kemampuan kolaborasi (Kemendikbud, 2017). Keempat keterampilan tersebut sangat penting dimiliki siswa, untuk mampu mengembangkan kemampuan belajar sepanjang hayat, peka terhadap peluang, dan beradaptasi terhadap perubahan pada ERI 4.0 (Zubaidah, 2018). E-learning terintegrasi Kearifan Lokal Bali berbasis learning and inovation skill atau 4C sangat baik diimplemntasikan pada anak remaja khusunya SMP. Anak remaja sudah mulai tahap operasional formal menurut perkembangan kognitif Piaget, memiliki kemampuan berpikir abstrak tentang ide dan alternatif pemecahan masalah, dengan proses informasi yang beradaptasi pemikiran mereka sendiri (Santrock, 2018; Woolfolk, 2019).

Berbagai penelitian telah dilakukan tentang pengintegrasian kearifan lokal dalam pembelajaran (Anwari, 2016; Ilhami, 2019; Pamungkas et al., 2017; Parwati, 2015; Setiawan, 2017; Suja, 2017; Wardani \& Wiyasa, 2020), tapi masih sangat jarang diterapkan dalam pembelajaran e-learning. Penelitian integrasi Kearifan Lokal Bali dalam pembelajaran hanya berfokus pada satu bagian saja, tidak mengembangan pembelajaran yang menintegrasikan kearifan lokal secara konperehensif yaitu sebagai konten (Husin \& Darsono, 2018; Suja, 2017), konteks (I. Suastra, 2017), dan sintaks (Pamungkas et al., 2017), apalagi pada e-learning. Selain itu, integrasi kearifan lokal hanya terkesan untuk melestasarikan kearifan lokal tersebut tidak mendorong learning and inovation skill siswa. Penelitian ini diharapkan mampu menunjukkan bahwa integrasi Kearifan Lokal Bali dalam e-learning IPA SMP, merupakan pengintegrasian pemikiran dan budaya lokal yang bersifat universal (mampu diterima dan diadaptasi oleh dunia). Hal tersebut berbasis learning and inovation skill yang diharapkan menghasilkan siswa yang peka terhadap permasalahan di lingkungan sekitarnya, cerdas, produktif, dan inovatif. E-learning yang dirancang dalam penelitian ini mengintegrasikan kerifan lokal berupa konten, konteks, dan sintaks. Konten keraifan lokal akan disesuaikan dengan jenis materi yang akan dibahas. Konteks kearifan lokal yang dikembangkan adalah konteks cara memperoleh pengetahuan, motivasi belajar, lingkungan belajar, dan pengembangan karakter.

Sintaks yang digunakan dalam pembelajaran ini adalah Tri Kaya Parisudha, dijelaskan sebagai berikut. Pertama, tahap manacika (berpikir yang baik dan benar), siswa diberikan pemahaman tentang literasi, critical thinking, dan cara memanfaatkanya dalam belajar IPA. Pada taham manacika siswa dihadapkan dengan isu aktual yang terhubung dengan materi dan memikirkan secara kritis alternatif solusi yang dapat digunakan. Kedua kayika (berbuat yang baik dan benar), pada tahap ini siswa diberikan praktik, praktikum, atau proyek yang bertujuan mengembangkan daya creativity (kreativitas), serta siswa 
diberikan ruang berinovasi. Ketiga tahap wacika (berbicara yang baik dan benar), siswa diberikan kesempatan presentasi dan diskusi secara daring, serta diberikan suatu forum diskusi berbasis chat yang membahas suatu permasalahan yang aktual, terbuka, dan kritis. Pada tahap ini, sebelumnya siswa diberikan aturan dan tata tertib presentasi dan diskusi. Tahap kedua ini, diharapkan mampu mengembangkan communication skills (kemampuan berkomunikasi) siswa. E-learning tersebut dikemas dalam bentuk pembelajaran kooperatif, dimana dalam proses belajar siswa dibagi menjadi beberapa kelompok kecil yang bertujuan untuk meningkatkan ability to work collaboratively (kemampuan untuk bekerja sama). Pada ketiga tahap pembelajaran ini juga akan diselipkan Kearifan Lokal Bali berupa konten dan konteks yang sesuai dengan materi yang dibahas. Sehingga pengembangan e-learning terintegrasi Kearifan Lokal Bali berbasis 4C pada mata pelajaran IPA SMP diharapkan mampu mendorong siswa untuk memahami materi pembelajaran IPA, menghubungkan materi dengan kearifan lokal, peka terhadap isuisu IPA, memanfaatkan pengetahuannya secara kreatif untuk belajar berkelanjutan, dan mampu berinovasi untuk menghasilkan suatu inovasi. Tujuan penelitian ini adalah untuk mendesain, melakukan uji coba, dan mengevaluasi hasil implementasi e-learning terintegrasi Kearifan Lokal Bali yang komperehensif berbasis 4C.

\section{METODE}

Penelitian ini dilaksanakan di SMP Negeri 1 Singaraja. Subjek penelitian ini adalah siswa kelas VIII dan guru IPA SMPN Singaraja. Sedangkan objek dari penelitian ini adalah rancangan e-learning terintegrasi Kearifan Lokal Bali berbasis 4C. Jenis penelitian yang dipilih adalah Research and Development $(R \& D)$ (Borg, 2014). Langkah-langkah penelitian mengikuti Borg dan Gall yaitu: (1) research and information collecting; (2) planning; (3) develop preliminary form of product; (4) preliminary field testing; (5) main product revision; (6) main field testing; (7) operational product revision; (8) operational field testing; (9) final product revision; and (10) dissemination and implementation. Prosedur penelitian yang dilakukan adalah: (1) Tahap I yaitu tahap pendahuluan yaitu analisis kurikulum, materi IPA dan Kearifan Lokal Bali yang berpeluang sebagai sintaks, konten, dan konteks pembelajaran; (2)Tahap II yaitu tahap perencanaan dan pengembangan e-learning terintegrasi Kearifan Lokal Bali berbasis 4C yang menghasilkan produk awal; (3) Tahap III yaitu tahap uji coba produk, evaluasi oleh ahli, dan sekelompok kecil siswa. Hasilnya adalah revisi produk yang diap dilakukan uji lapangan; (4) Tahap IV yaitu tahap uji coba lapangan yaitu implementasi model e-learning dengan target subjek 40-50 orang siswa dengan metode sampling kuota, dalam penelitian ini kamu menggunakan dua kelas yang diambil secara acak yaitu 8A5 dan 8A10 dengan jumlah 66 siswa (Sugiyono, 2017), revisi produk akhir, dan diseminasi produk.

Teknik pengambilan data yang digunakan adalah observasi, wawancara, kuesioner dan tes (Sugiyono, 2017). Observasi akan dilakukan untuk mengumpulkan data: (1) analisis materi IPA dan kearifan lokal Bali; dan (2) Identifikasi permasalahan yang dialami pada saat ujicoba produk dan ujicoba lapangan. Wawancara digunakan untuk mengumpulkan data: (1) analisis materi IPA dan kearifan lokal Bali; dan (2) mengidentifikasi temuan-temuan yang dapat digunakan sebagai bahan revisi saat ujicoba produk dan ujicoba lapangan. Kuisioner akan dipergunakan untuk mengumpulkan data pendapat ahli media, ahli isi, guru, dan siswa terhadap hasil pengembangan awal e-learning terintegrasi Kearifan Lokal Bali berbasis 4C yang dikembangkan pada tahap ujicoba produk maupun ujicoba lapangan. Tes digunakan pada tahap uji coba lapangan untuk melihat hasil belajar IPA sebelum dan sesudah implementasi $e$ learning terintegrasi Kearifan Lokal Bali berbasis 4C. Data yang terkumpul akan dianalisis secara kualitatif dan kuantitatif. Data yang diperoleh dari hasil observasi, interview dan kuisioner akan dianalisis secara kualitatif dengan menggunakan tehnik analisis Interactive data Analysis Model Miles dan Huberman yang terdiri dari tiga tahapan yakni, data reduction, data display, dan conclusion drawing and verification (Sugiyono, 2017). Sedangkan, data kuantitatif dari hasil tes pada saat uji coba lapangan akan dianalisis menggunakan analisis statistik deskriptif dan inferensial paired sample test jika memenuhi uji asumsi, jika tidak digunakan Wilcoxon Signed Rank Test (Bluman, 2012), dengan komputasi aplikasi IBM SPSS 26 (George, D. \& Mallery, 2020).

\section{HASIL DAN PEMBAHASAN}

Hasil

Tahap I yaitu tahap pendahuluan yaitu analisis kurikulum, materi IPA dan Kearifan Lokal Bali yang berpeluang sebagai sintaks, konten, dan konteks pembelajaran yang dilakukan melalui zoom meeting peneliti bersama guru IPA Kelas VIII SMPN 1 Singaraja ahli konten dan ahli media Hal yang dilakukan antara lain: (a) Analisis Kurikulum dan Materi IPA; dan (b) Analisis kearifan Lokal Bali untuk Integrasi ke e-learning. Kegiatan ini dilakukan secara daring menggunakan google meet. Tahap pendahuluan disajikan 
pada Gambar 1. Berdasarkan hasil analisis materi pada kurikulum SMP Kelas VIII terdapat enam materi pada semester genap dan lima materi pada semester ganjil. Berdasarkan hasil analisis materi diperoleh bahwa semua materi dapat digunakan untuk pengembangan Pengembangan e-learning terintegrasi kearifan lokal Bali Berbasis 4C. Meskipun ada kendala kesulitan mencari konten yang sejenis pada beberapa materi. Namun, hal tersebut dapat ditutupi dengan mengintegrasikan kearifan lokal Bali dalam bentuk konteks pada materi tersebut. Guru dan ahli menyarankan untuk fokus hanya mengembangkan salah satu materi saja dan disesuaikan dengan jadwal pembelajaran di Kelas VIII SMPN 1 Singaraja.

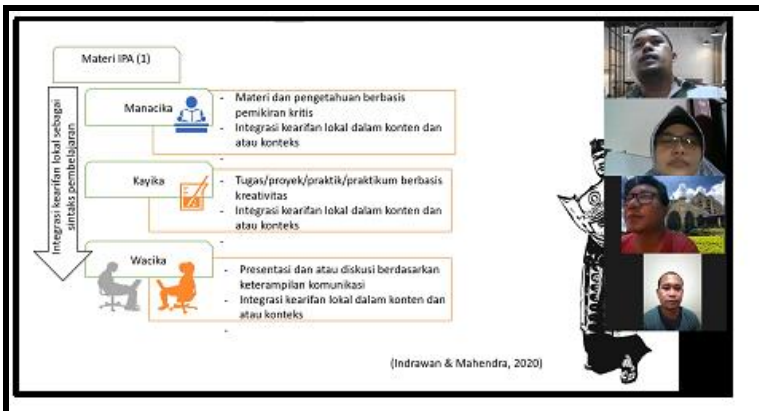

a. Penjelasan Konsep Pengembangan

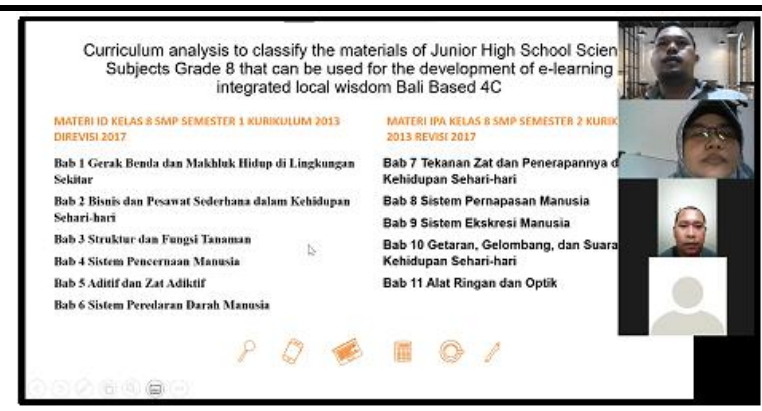

b. Pembahasan Analisis Kurikulum dan Materi IPA Kelas VIII

Gambar 1. Tahap Pendahuluan

Tahap II yaitu tahap perencanaan dan pengembangan e-learning terintegrasi Kearifan Lokal Bali berbasis 4C. Tahap ini dilakukan melalui proses pengumpulan informasi (Analisis Kebutuhan rancangan e-learning terintegrasi Kearifan Lokal Bali berbasis 4C) melalui observasi RPP, kegiatan pembelajaran daring, dan wawancara dengan guru kelas VIII SMPN 1 Singaraja dan beberapa siswa. Hasil analisis kebutuhan antara lain: (1) Pada pembelajaran daring pada materi cermin cembung sinkron guru telah melakukan proses pendahuluan (salam, apersepsi, dan motivasi); kegiatan inti (pada peninjuan konsep dan latihan berpatokan pada Buku IPA 8) dengan beberapa penggayaan yang dilakukan guru namun belum mengintegrasikan kearifan lokal Bali di dalamnya, beberapa siswa secara mandiri siswa diberikan kesempatan presentasi hasil latihan menggambar sinar pada cermin cembung dan mendiskusikan hasilnya; Pada kegiatan akhir siswa diberikan tugas latihan pada google classroom, dan sebelum pembelajaran berakhir dilakukan doa bersama-sama dan salam penutup.; (2) Perlu dalam e-learning diintegrasikan kearifan lokal Bali dalam bentuk sintaks, konteks, maupun konten untuk menguatkan pemahaman dan kecintaan terhadap kearifan lokal yang ada di Bali, khususnya yang terkait dengan materi pembelajaran IPA Kelas 8.; (3) Learning and inovation skill perlu dikembangkan lebih banyak dalam proses pembelajaran, siswa telah dikembangkan kemampuan berkomunikasi (Communication skills) dengan memberikan peluang beberapa siswa mempresentasikan hasil latihannya namun, belum secara aktif melibatkan keseluruhan siswa dan masih berpatokan pada buku IPA Kelas 8, perlu lebih banyak pengayaan dan pemberian isue/permasalahan kontektual untuk pengembangan Critical thinking siswa. Siswa perlu diberikan alternatif praktek/praktikum yang diarahkan mengembangkan kreativitas sehingga menghasilkan produk sederhana yang menarik dan inovatif menunjang proses pembelajaran sebagai pengembangan dari Creativity. Pada kegiatan prakterk/praktikum/membuat proyek dan presentasi/diskusi siswa perlu belajar dalam kelompok kecil untuk mengembangkan Ability to work collaboratively, meskipun ini akan membutuhkan waktu yang lebih banyak namun diharapkan pengembangan Learning and inovation skill menjadi lebih baik.

Dilakukan zoom meeting untuk mendesain produk rancangan e-learning terintegrasi Kearifan Lokal Bali berbasis 4C bersama guru selaku ahli konten, ahli media pembelajaran. Tiga ahli belum bisa hadir saat zoom meeting sehingga komuniksi dilanjutkan via telpon dan whatshap untuk memberikan masukan. Para ahli materi dan e-learning menyepakati materi yang akan digunakan adalah materi "Struktur dan Fungsi Tanaman" dalam pengembangan E-Learning Terintegrasi Kearifan Lokal Bali Berbasis 4C. Validasi desain dilakukan oleh dua ahli yang merupakan ahli e-learning, dosen IT dan dosen teknologi pendidikan. Hasil validasi menunjukkan nilai rerata validasi e-learning dan media adalah 92,65 masuk kriteria sangat baik, dengan nilai pada aspek e-learning 91,35 dan aspek media pembelajaran 96,88. Artinya desain sudah disetujui dan tidak perlu direvisi, karena tidak ada catatan dari tim ahli. Pengembangan e-learning terintegrasi Kearifan Lokal Bali berbasis 4C dilanjutkan. Revisi desain produk 
rancangan e-learning dan pembuatan produk berdasarkan revisi desain. Sedang dilakukan revisi materi dan pembuatan produk berdasarkan masukan dari ahli materi/konten dan ahli media pembelajaran. Setelah, selesai akan dikomunikasikan kembali dengan ahli konten/materi dan media sebelum dilakukan uji coba produk. Hasil pengembangan e-learning terintegrasi Kearifan Lokal Bali berbasis 4C tersebut kemudian dilakukan ujicoba produk yang dilakukan oleh ahli materi, ahli media, dan 10 orang siswa.

Tahap III yaitu tahap uji coba produk, evaluasi oleh ahli, dan sekelompok kecil siswa. Hasilnya adalah revisi produk yang diap dilakukan uji lapangan. Uji coba pemakaian produk pada kelompok kecil melibatkan dua orang ahli materi, dua orang ahli e-learning dan 10 orang siswa. Temuan dan masukan pada tahap ini digunakan untuk revisi produk rancangan e-learning terintegrasi Kearifan Lokal Bali berbasis 4C. Validasi materi/konten dilakukan oleh dua ahli materi, dosen biologi dan guru yang mengajar di kelas 8. Hasil rerata penilaian kedua ahli materi/konten adalah 96,15 masuk kualifikasi sangat baik, layak diujicobakan/diimplementasikan. Salah satu ahli memberi masukan agar integrasi konten kearifan lokal juga menyinggung makna filosofinya. Validasi e-learning dilakukan oleh ahli validasi yang sama dengan validasi desain. Sedangkan hasil rerata penilaian dari kedua ahli e-learning adalah 93,38 masuk kualifikasi sangat baik. Namun ada masukan yang diberikan oleh ahli yaitu pada saat implementasi perlu dijealaskan melalui menu forum urutan kegiatan pembelajaran yang harus dilaksanakan, sehingga siswa tahu bahwa kegiatan pembelajaran manacika, kayika, dan wacika adalah satu kesatuan. Hasil respon 10 orang siswa yang ikut dalam ujicoba terkait efektivitas e-learning yang dikembangkan berdasarkan CCAF (Allen, 2016), hasil analisis nilai rerata respon siswa adalah 92,03 masuk kualifikasi sangat baik, layak dilakuka uji coba lapangan. Hasil perubahan produk berdasarkan revisi dan masukan para ahli, guru, dan siswa akan digunakan pada uji coba lapangan.

Tahap IV yaitu tahap uji coba lapangan yaitu implementasi produk rancangan e-learning pada kelompok siswa yang merupakan sampel penelitian, revisi produk akhir, dan diseminasi produk. Implementasi e-learning terintegrasi Kearifan Lokal Bali berbasis 4C secara asinkron menggunakan google classroom dan secara sinkron menggunakan google meet yang familiar digunakan oleh para guru. Sebelum implementasi kegiatan dilakukan perkenalan cara pembelajaran dengan e-learning terintegrasi Kearifan Lokal Bali berbasis 4C melalui google meet. Tahap manacika dilakukan di rumah oleh siswa dengan mempelajari konsep dasar "Struktur dan Fungsi Tumbuhan" serta konten dan konteks kearifan lokal Bali yang terakait dengan materi tersebut. Setelah siswa merasa sudah memahami materi kemudian mereka akan melanjutkan tahap Kayika yaitu siswa mengerjakan tugas dalam kelompok kecil yang telah dibentuk oleh guru sebelumnya. Hasil kegiatan Kayika ini kemudian dipresentasikan dan didiskusikan secara sinkron melalui google meet.

Pada saat awal kegiatan siswa diberikan kesempatan untuk mengerjakan pre-test untuk mengetahui pengetahuan awal siswa. Pre-test dilakukan secara daring menggunakan google form yang diikuti oleh 53 siswa dari kelas 8A5 dan 8A10 dari 66 total siswa di dua kelas tersebut. Setelah pre-test dilanjutkan dengan kegiatan pengenalan e-learning terintegrasi Kearifan Lokal Bali berbasis 4C. Pengenalan e-learning terintegrasi Kearifan Lokal Bali berbasis 4C kepada guru dan siswa secara sinkron melalui google meet menjelaskan tentang apa, kenapa, dan bagaimana proses pembelajaran yang akan diimplementasikan. Beberapa anak bertanya antara lain: (1) terkait format file yang diunggah pada tahap kayika; (2) pada saat presentasi dan diskusi siapa sebagai penilai yang menjadi penilai presentasi; (3) apakah boleh mengembangkan lagi materi terkait kearifan lokal Bali; dan (4) berapa kelompok yang presentasi dalam satu kali pertemuan. Semua pertanyaan tersebut dijawab dengan jelas oleh guru yang telah berkoordinasi sebelumnya dengan peneliti, jika ada miskonsep terkait e-learning terintegrasi Kearifan Lokal Bali berbasis 4C maka peneliti berperan meluruskan. Peneliti dalam proses implementasi hanya berberan sebagai pengamat, dan tidak mencampuri proses pembelajaran, untuk mengurangi bias penelitian. Peneliti diperkenalkan sebagai team teaching yang tugasnya hanya sebagai pengamat kegiatan. Siswa tidak diberitahu bahwa kegiatan ini adalah penelitian, hanya dijelaskan bahwa akan dilakukan pembelajaran e-learning e-learning terintegrasi Kearifan Lokal Bali berbasis 4C di kelas tersebut.

Setelah kegiatan wacika siswa diberikan post-test untuk mengetahui pemahaman konsep yang sudah dicapai siswa setelah mengikuti proses pebelajaran. Post-test diikuti oleh 50 orang siswa dari total 66 siswa pada kelas 8A5 dan 8A10. Setelah dilakukan pengecekan data hanya 44 orang yang mengikuti pre-test dan post test, sisanya 22 orang 9 orang hanya mengikuti pre-test saja, 6 orang hanya mengikuti post-test saja, dan sisanya tidak mengikuti baik pre-test maupun post-test karena tidak hadir pada saat kegiatan dilaksanakan. Sehingga hanya data dari 44 siswa ini saja yang digunakan dalam analisis statistik, ini sudah memenuhi jumlah sampel kuota yang ditargetkan yaitu 40-50 siswa sebagai subjek uji coba lapangan. Data yang terkumpul dilakukan uji normalitas sebaran data enggunakan Shapiro-Wilk dikomputasi dengan IBM SPSS 26 for Windows. Hasil komputasi menunjukkan nilai sig. pada post-test lebih sama dengan 0,05; artinya data post-test tidak berdistribusi normal sehingga uji statistik yang digunakan adalah nonparametrik yaitu Wilcoxon Signed Rank Test. Hasil komputasi Wilcoxon Signed Rank Test 
menggunakan IBM SPSS 26 for Windows menunjukkan bahwa terdapat perbedaan signifikan antara data nilai pre-test dan post-test, dimana rerata nilai pre-test adalah 40,15 dan post-test 66,10. Maknanya terdapat penambahan pengetahuan siswa melalui pembelajaran dengan e-learning terintegrasi Kearifan Lokal Bali berbasis 4C; meskipun keterserapan materi secara klasikal hanya mencapai $66,10 \%$ masuk kualifikasi cukup. Nila korelasi $0,578\left(r^{2}=0,334\right)$ dengan sig. 0,000 menunjukkan bahwa pengetahuan awal siswa berkorelasi secara signifikan dengan nilai akhir sebesar 33,4\% dalam uji coba ini. Respon siswa terhadap implementasi e-learning terintegrasi Kearifan Lokal Bali berbasis 4C ditunjukkan pada Gambar 8. Rerata nilai respon siswa adalah 90,23 masuk kriteria sangat baik. Diseminasi e-learning terintegrasi Kearifan Lokal Bali berbasis 4C dengan memberikan produk kepada guru untuk disebarkan diimplementasikan dan dikembangkan lebih lanjut.

\section{Pembahasan}

Proses desain e-learning terintegrasi Kearifan Lokal Bali berbasis 4C melalui proses analisis kurikulum dan materi yang melibatkan guru ahli materi/konten dan ahli e-learning. Desain e-learning mempertimbangkan integrasi kearifan Bali berupa sintaks, konteks, dan konten dalam pembelajaran, serta cara pengembangan $4 \mathrm{C}$ dalam proses pembelajaranya. Fokus materi yang akan digunakan untuk pengembangan dan implementasi e-learning terintegrasi Kearifan Lokal Bali berbasis 4C adalah materi "Struktur dan Fungsi Tumbuhan". Tahap-tahap pembelajaran e-learning terintegrasi Kearifan Lokal Bali berbasis 4C terdiri atas beberapa langkah, Tahap manacika dilakukan oleh siswa secara individu di rumah masing-masing, siswa dalam proses ini mempelajari materi dasar melalui buku dan video pembelajaran yang ada pada menu manacika, dan tidak menutup kemungkinan belajar dari berbagai sumber lain. Tahap manacika dilakukan oleh siswa di rumah, agar siswa saat pertemuan sinkron sudah memiliki konsep-konsep dasar yang dibutuhkan. Belajar konsep dasar lebih awal membuat siswa lebih siap dalam sesi presentasi dan diskusi saat kegiatan daring sinkron. Materi yang ada pada tahap manacika mengintegrasikan konsep-konsep dasar struktur dan fungsi tumbuhan dengan kearifan lokal Bali, sehingga lebih komperehensif dan kontekstual. Integrasi materi misalnya terkait dengan bagian-bagian tumbuhan yang digunakan sebagai bahan banten (alat upacara umat hindu di Bali), berbagai tumbuhan yang digunakan untuk upacara tertentu, dan klasifikasi hasil bumi (sarwa pala) seperti pala gantung, pala bungkah, pala wija, dan pala rambat yang banyak digunakan saat pembuatan penjor sebelum Hari Raya Nyepi. Klasifikasi hasil bumi (sarwa pala) sebenarnya termasuk etnotaksonomi yang menjadi salah satu kearifan lokal di Bali. Etnotaksonomi merupakan ilmu berkaitan dengan klasifikasi yang dilakukan masyarakat lokal serta memahami bagaimana keanekaragaman hayati diatur dan dikonservasi (Albuquerque, 2019; Mourão et al., 2018). Etnotaksonomi sarwa pala ini dihubungkan dengan alat perkembangbiakan vegetatif tumbuhan serta jenis tumbuhan monokotil dan dikotil. Pada tahap manacika terdapat video animasi whiteboard yang berisi materi-materi dasar dan integrasi kearifan lokal. Pembelajaran dengan pemberian materi sebelum pembelajaran di kelas (pre-class) lebih efektif menggunakan video (Abdulrahaman et al., 2020; Nouri, 2016; Rabin et al., 2021; van Alten et al., 2020).

Tahap kayika siswa bekerja secara berkelompok membuat powerpoint terkait apa yang mereka pahami dan mengerjakan empat tantangan belajar terkait integrasi kearifan lokal antara lain mencari sepuluh jenis pala bungkah dan klasifikasikan secara biologi dalam kategori umbi batang, umbi akar, umbi lapis, dan rimpang; membuat daftar sepuluh buah yang banyak digunakan untuk pembuatan banten di Bali dan pilah mana mana buah dikotil dan monokotil; mencari berbagai manfaat tebu selain sebagai bahan banten/canang saraswati; dan membuat gambar struktur daun, batang, dan akar pohon beringin (Ficus benjamina) yang sering prosesi upacara digunakan pada proses ngaben beserta filosofinya. Semua hal tersebut dibuat dalam bentuk powerpoint yang diunggah melalui google form yang telah disediakan. Tahap wacika siswa melakukan presentasi diskusi secara daring. Kelompok penyaji mempresentasikan hasil kerja mereka berupa powepoint. Hasil penelusuran informasi terkait konsep struktur dan fungsi tumbuhan serta integrasi kearifan lokal Bali, gambar struktur bagian tumbuhan beringin (Ficus benjamina), dan mereka mampu menjelaskan filosofi terkait kearifan lokal. Proses diskusi difasilitasi oleh guru, pertanyaan dan tanggapan/jawaban relevan dengan materi yang terintegrasi kearifan lokal Bali. Pengembangan keterampilan kritis siswa terlihat pada bagai mana mereka mengumpulkan informasi berbagai jenis pala bungkah dan memilahnya berdasarkan jenis perkembangan vegetatif yaitu umbi batang, umbi akar, umbi lapis, umbi atau rimpang. Pengembangan kreativitas terlihat pada saat mereka menampilkan hasil ada yang menunjukkan berupa tabel ada yang menunjukkan berupa gambar dan tulisan. Hal tersebut juga dapat dilihat dari pemilahan jenis buah dikotil dan monokotil yang sering digunakan saat membuat banten/pajegan.

Rerata penilaian kedua ahli materi/konten adalah 96,15 masuk kualifikasi sangat baik, layak diujicobakan/diimplementasikan. Rerata penilaian dari kedua ahli e-learning adalah 93,38 masuk kualifikasi sangat baik. Namun ada masukan yang diberikan oleh ahli yaitu pada saat implementasi perlu 
dijealaskan melalui menu forum urutan kegiatan pembelajaran yang harus dilaksanakan, sehingga siswa tahu bahwa kegiatan pembelajaran manacika, kayika, dan wacika adalah satu kesatuan. Sesuai masukan ahli materi/konten dan e-learning: (1) diberikan contoh makna filosofi kearifan lokal Bali pada materi video; dan (2) pada menu forum google classroom diberikan keterangan intruksi langkah pembelajaran untuk mempermudah siswa belajar. Kearifan lokal pada konteks etnoekologi terdisi dari tiga aspek yaitu kosmos, corpus, dan praxis (Albuquerque,2019; Pauli et al., 2016), dimana mitos dan filosofi kearifan lokal merupakan bagian dari kosmos yang tidak dapat terlepaskan dari nilai corpus (aspek keilmiahan/biologi) dan praxis (aspek implementasi/teknis). Rerata respon siswa pada uji coba kelompok kecil adalah 92,03 masuk kualifikasi sangat baik dan saat uji coba lapangan (kelompok besar) adalah 90,23 masuk kriteria sangat baik. Penilaian efektivitas e-learning diukur berdasarkan Context, Challenge, Activity, dan Feedback atau yang dikenal dengan CCAF (Allen, 2016). Aspek konteks (context) meninjau e-learning berdasarkan keterkaitan materi/konten pembelajaran dengan kehidupan sehari-hari, budaya lokal Bali, dan implementasi kehidupan sehari-hari. Aspek tantangan (challenge) meninjau e-learning berdasarkan kejelasan dan spesifik tidaknya tugas yang diberikan, tantangan mencari informasi untuk pengayaan, dan kejelasan batasan waktu pengerjaan tugas yang sesuai dengan beban tugas.tugas yang diberikan. Aspek aktivitas (activity) meninjau e-learning berdasarkan kejelasan intruksi langkah-langkah pembelajaran yang diberikan, pengalaman belajar yang komperehensif, pembelajaran yang memanfaatkan berbagai panca indra, dan peran e-learning mengembangkan 4C. Respon balik (feedback) meninjau e-learning berdasarkan peran guru memberikan respon balik positif dan relevan pada pembelajaran daring sinkron dan asinkron yang diimplementasikan.

Hasil komputasi Wilcoxon Signed Rank Test menunjukkan nilai sig. 0,000 artinya terdapat perbedaan signifikan antara data nilai pre-test dan post-test, dimana rerata nilai pre-test adalah 40,15 dan post-test 66,10. Nilai postes 66,10 masuk kualifikasi cukup baik, namun masih dibawah standar nilai sekolah yaitu 70. Hal ini menurut guru diasumsikan terjadi karena pemberian post-test setelah kegiatan wacika (presentasi diskusi) mestinya ada jeda, misalnya minggu depanya. Hal tersebut bertujuan agar lebih siswa mempersiapkan diri untuk mengikuti post-test. Selain itu, dalam proses pembelajaran peneliti mestinya memperhatikan gaya belajar siswa sehingga e-learning yang dikembangkan optimal. Nila korelasi 0,578 $\left(\mathrm{r}^{2}=0,334\right)$ dengan sig. 0,000 menunjukkan bahwa pengetahuan awal siswa berkorelasi secara signifikan dengan nilai akhir sebesar 33,4\% dalam uji coba ini. Pengetahuan awal berpengaruh penambahan memori baru saat siswa beajar (Bellana et al., 2021), yang berpengaruh terhadap hasil belajar siswa. Siswa dengan pengetahuan awal lebih banyak menunjukkan kinerja yang lebih baik pada kelompok kolaboratif (Zambrano R. et al., 2019). Selain itu, Siswa dengan pengetahuan awal lebih baik mengungguli siswa yang pengetahuan awalnya kurang pada hasil belajar individu (Bellana et al., 2021; Zambrano R. et al., 2019).

Penelitian ini menggunakan sintak Tri Kaya Parisudha yang terdiri dari manacika, kayika, dan wacika (Indrawan \& Jaka, 2021). Pada kegiatan manacika siswa diberikan konsep dan diajak berpikir kritis terkait permasalahan-permasalahan riil yang ada di lingkungan mereka terkait materi yang dipelajari. Pada langkah kayika siswa diajak melakukan percobaan atau praktikum terkait materi yang dipelajari, dan tentunya menekankan pengembangan kreativitas peserta didik. Proses kayika diharapkan mampu menghasilkan produk/suatu hasil yang kemudian dapat dipresentasikan dan didiskusikan pada tahap wacika di dalam pembelajaran daring sinkron atau dalam forum diskusi yang disediakan melalui media tertentu. Learning and inovation skill akan dikembangkan pada siswa melalui ketiga langkah tersebut. Critical thinking dikembangkan pada saat tahap manacika. Kemampuan berpikir kritis dikembangkan dengan memberikan permasalahan riil berkaitan dengan materi yang dipelajari, kemudian siswa diberikan waktu untuk mencari alternatif solusi sebelum dibahas dalam tahap wacika. Creativity dikembangkan dalam e-learning melalui proses kayika. Siswa melakukan praktek/praktikum yang diarahkan mengembangkan kreativitas sehingga menghasilkan produk yang menarik dan inovatif menunjang proses pembelajaran. Communication skills dikembangkan melalui proses diskusi presentasi dengan mengarahkan pada komunikasi efektif, sopan, dan wajar. Ability to work collaboratively dikembangkan dalam proses kayika dan wacika yang dikemas dalam bentuk pembelajaran kooperatif. Siswa pada langkah kayika dan wacika dibagi menjadi kelompok kecil yang terdiri dari 4-5 orang berkolaborasi dalam tugas/proyek/praktek/praktikum dan presentasi hasilnya.

Integrasi kearifan lokal Bali dalam bentuk konten misalnya pada materi: (1) Gerak Benda dan Makhluk Hidup di Lingkungan Sekitar dengan menghubungkan dengan tri prama dan makna karma sebagai gerak; (2) Usaha dan Pesawat Sederhana dalam Kehidupan Sehari-hari diintegrasikan dnegan konsep kreativas model tri datu: warna merah simbol mencipta (how to create), warna hitam simbol memelihara (how to maintain), dan warna putih simbol perubahan (how to change) (Sutajaya, 2020). Pesawat sederhana adalah bagian dari hasil kreativitas manusia untuk mempermudah dan menyederhanakan pekerjaanya; (3) Struktur dan Fungsi Tanaman dihubungkan dengan konten taru 
prmana, sarwa pala dan tanaman bahan upakara yadnya di Bali; (4) Sistem Pencernaan Manusia dan Aditif dan Zat Adiktif dihubungkan dengn konten gending rare Buyung dan Merta Dahar yang berkaitan dengan penyakit sistem pencernaan dan sumber-sumber makanan sehat dan alami (Parmini, 2021). Selain itu dapat dihubungkan dengan konsep Sauca (Suci lahir batin) dan Aharalagawa (makan sehat secukupnya); (5) Sistem Peredaran Darah Manusia dihubungkan dengan akrodha (tidak marah) dan Aharalagawa (makanan sehat menhindari penyakit peredaran darah); (6) Sistem Pernapasan Manusia dapat dihubungkan dengan pranayama yaitu pengaturan napas untuk kesehatan jasmani dan rohani; dan (6) Getaran, Gelombang, dan Suara dalam Kehidupan Sehari-hari dihubungkan dengan konten jenis-jenis suara gamelan pada upacara panca yadnya, karena jenis gelombang suara menimbulkan suasana dan perasaan yang berbeda. Integrasi kearifan lokal sebagai konteks motivasi belajar "Joh pejalane, liu ne tepukin" artinya semakin jauh perjalanan semakin banyak hal yang ditemui, makna kearifan lokal ini pengamalan memberi pengetahuan lebih atau lebih banyak belajar lebih banyak ilmu yang diperoleh; "puntul-puntulan tiyuke yen sangih pedas dadi mangan" pisau yang tumpul jika diasah akan menjadi tajam, sebodoh-bodohnya orang jika belajar maka akan semakin pintar (Parmini, 2021). Beberapa Satwa Bali juga memiliki pesan moral dan nilai motivasi yang dapat digunakan sebagai alternatif konteks motivasi belajar dalam e-learning misalnya satwa I jalak nantang I kebo nginem yeh pasih, pengetahuan dapat menjadi solusi untuk permasalahan hidup yang kita miliki (Parwati, 2015; Suja, 2017). Selanjutnya, de gancangan tindak kuangan daya pesan ini dapat digunakan dalam konteks ketelitian dan kehati-hatian dalam bertindak, melakukan praktikum atau menyimpulkan hasil diskusi dalam proses pembelajaran (Parwati, 2018).

Integrasi kearifan lokal dalam bentuk konteks dapat ditinjau dari: (1) Tri Kaya Parisudha yaitu berpikir, berkata, dan berbuat yang baik dalam kehidupan sehari-hari; (2) Tidak melakukan bullying yang menyebabkan luka psikologis terhadap orang lain dengan menerapkan tatwamasi. Berperilaku baik, menghargai, dan menghormati orang lain sebagaimana kita menghormati dan menghargai diri sendiri; (3) Memberikan contoh yang baik sehingga menjadi tauladan bagi banyak orang dengan mempublikasikan kegiatan yang mengimplementasikan "Sagilik-Saguluk Salunglung Sabayantaka, Paras-Paros Sarpanaya, Saling Asah, Asih, Asuh" yang artinya bersatupadu, saling menghargai pendapat orang lain, dan saling mengingatkan, saling menyayangi, saling tolong-menolong (Yudha et al., 2020); (4) Pengembangan memprioritaskan swadharma (kewajiban pribadi) dan dharma negara misalnya cinta tanah air, sadar pajak, dan sebagainya (I P.O. Indrawan et al., 2019).

Terkait konteks bekerjasama dan kolaborasi ada beberapa kearifan lokal yang dapat digunakan misalnya: (1) Caruk gong, muah aud kelor maknanya dalam pekerjaan kelompok semua harus berperan serta; (2) De liunan krebek kuangan ujan maknanya sedikit bicara banyaklah bekerja; (3) Gede kayu, gede papanne maknanya orang yang bekerja lebih pasti memperoleh hasil lebih (I P.O. Indrawan \& Jaka, 2021). Terkait konteks kemampuan berkomunikasi misalnya paksi bina paksa orang yang berbeda memiliki pemikiran berbeda, jadi perlu adanya toleransi dan pemikiran terbuka. Integrasi kearifan lokal dalam konteks pembelajaran sangat banyak dapat disematkan khususnya dalam penanaman karakter bangsa, kolaborasi, dan komunikasi dalam proses pembelajaran (Gunawan, 2019; Kurniawan, 2021; I. W. Suastra et al., 2017; Sudarmin, 2018). Keterbatasan dan impliaksi penelitian ini adalah: (1) Jumlah subjek uji coba yang digunakan masih sedikit melum representatif, mestinya dilakukan penelitian kuasi eksperimental dengan jumlah sampel yang lebih representatif; (2) Belum mempertimbangkan faktor gaya belajar dan kesulitan belajar daring siswa yang terkait dengan proses e-learning; (3) Integrasi kearifan lokal Bali yang kami kembangkan hanya untuk sintaks tri hita karana selanjutnya dapat dikembangkan pada sintaks kearifan lokal yang lain misalnya catur pramana; dan (4) Integrasi kearifan lokal dalam bentuk konten dan konteks yang peneliti kembangkan baru sebatas pada materi "Struktur dan Fungsi Tumbuhan" perlu dikembangkan lebih jauh pada berbagai materi lain di kelas 8 dan SMP secara umum.

\section{SIMPULAN}

Desain e-learning sudah mengintegrasi kearifan lokal Bali secara komprehensif serta mengembangkan 4C dengan kualitas masuk kualifikasi sangat baik berdasarkan penilain ahli materi dan e-learning. Hasil uji coba e-learning melalui pengujian Wilcoxon Signed Rank Test menunjukkan ada perbedaan signifikan antara data nilai pre-test dan post-test. Evaluasi e-learning melalui respon siswa dan guru berdasarkan CCAF masuk kriteria sangat baik. Peneliti dan guru dapat menggunakan ini sebagai alternatif model dan melakukan eksperimen dengan mempertimbangkan gaya belajar dan pengukuran detail pada 4C pada siswa. 


\section{UCAPAN TERIMAKASIH}

Terimakasih untuk KEMRISTEKBRIN yang telah membiayai penelitian ini dengan kontrak 069/E4.1/AK.04.PT/2021, LLDikti Wilayah 8, and Politeknik Ganesha Guru yang memfasilitasi prosesnya.

\section{DAFTAR PUSTAKA}

Abdulrahaman, M. D., Faruk, N., Oloyede, A. A., Surajudeen-Bakinde, N. T., Olawoyin, L. A., Mejabi, O. V., Imam-Fulani, Y. O., Fahm, A. O., \& Azeez, A. L. (2020). Multimedia tools in the teaching and learning processes: A systematic review. Heliyon, 6(11), e05312. https://doi.org/10.1016/j.heliyon.2020.e05312.

Albuquerque, U.P., Piava, R.F., Cruz, L. V. (2019). Methods and Techniques in Ethnobiology and Ethnoecology (2nd ed.) (Issue January). https://link.springer.com/book/10.1007/978-1-4614-8636-7.

Allen, M. W. (2016). Michael Allen's Guide to e-Learning (2nd Ed.). John Wiley \& Sons, Inc.

Anwari, A. (2016). Biological science learning model based on Turgo's local wisdom on managing biodiversity. In AIP Conference Proceedings (Vol. 1708). https://doi.org/10.1063/1.4941146.

Barbierato, E., Campanile, L., Gribaudo, M., \& Iacono, M. (2021). Simulation Modelling Practice and Theory Performance evaluation for the design of a hybrid cloud based distance synchronous and asynchronous learning architecture. Simulation Modelling Practice and Theory, 109(March), 102303. https://doi.org/10.1016/j.simpat.2021.102303.

Bellana, B., Mansour, R., Ladyka-Wojcik, N., Grady, C. L., \& Moscovitch, M. (2021). The influence of prior knowledge on the formation of detailed and durable memories. Journal of Memory and Language, 121(June), 104264. https://doi.org/10.1016/j.jml.2021.104264.

Bluman, A. (2012). Elementary Statistic: Step by Step Aproach, 8th Ed. McGraw-Hill.

Borg, G. (2014). Applying Educational Research: How to Read, Do, and Use Research to Solve Problems of Practice. In INew York and london. Longman publishing Inc.

Dunwill, E. (2016). Changes That Will Shape the Classroom of the Future: Making Education Fully Technological.

George, D. \& Mallery, P. (2020). IBM SPSS Statistic 26 Step by Step (A Simple Guide and Reference). Taylor \& Francis Group.

Gunawan, Y. Y. (2019). The analysis of students' critical thinking skill through ethnoscience instruction integrated on the topic of magnetic field. In AIP Conference Proceedings (Vol. 2194). https://doi.org/10.1063/1.5139765.

Husin, V. E. R., \& Darsono, T. (2018). Integrasi Kearifan Lokal Rumah Umekbubu dalam Bahan Ajar Materi Suhu dan Kalor untuk Meningkatkan Motivasi dan Hasil Belajar Siswa SMA. Physics Communication, 2(1), 26-35. https://doi.org/10.15294/physcomm.v2i1.11491.

Ilhami, A. (2019). Implementation of science learning with local wisdom approach toward environmental literacy. In Journal of Physics: Conference Series (Vol. 1157, Issue 2). https://doi.org/10.1088/1742-6596/1157/2/022030.

Indrawan, I P. O., Pramana, M. I. W., \& Gunawan, K. D. . (2019). Developing Tri Kaya Parishida Based Blended Learning Media Using Adobe Captive for Probstat Courses. Journal of Education Research and Evaluation, 3(3), 157. https://doi.org/10.23887/jere.v3i3.21858.

Indrawan, I P.O., \& Jaka, I. G. (2021). The Integration of Balinese Local Wisdom Based on 4C in E-Learning of Science Subjects for Grade 8 at SMPN 1 Singaraja. 15, 204-214.

Indrawan, I P.O., Jude Saskara, G. A., \& Budi Wijaya, I. K. W. (2019). Kreativitas dan Motivasi Belajar Mahasiswa dalam Implementasi Blended Learning Berbasis Bali. International Journal of Natural Science and Engineering, 3(2), 70. https://doi.org/10.23887/ijnse.v3i2.22194.

Indrawan, I Putu Oktap, Sudirgayasa, I. G., \& Wijaya, I. K. W. B. (2020). Integrasi Kearifan Lokal Bali di Dunia Pendidikan. Prosiding Seminar Nasional Webinar Nasional Universitas Mahasaraswati Denpasar, 3, 189-194. https://e-journal.unmas.ac.id/index.php/webinaradat/article/view/1181.

Jan, A. (2020). A phenomenological study of synchronous teaching during COVID-19: A case of an international school in Malaysia. Social Sciences \& Humanities Open, 2(1), 100084. https://doi.org/10.1016/j.ssaho.2020.100084.

Kemendikbud. (2017). Pendidikan Karakter Dorong Tumbuhnya Kompetensi Siswa Abad 21.

Kurniawan, R. (2021). The validity of e-module based on guided inquiry integrated ethnoscience in high school physics learning to improve students' critical thinking. In Journal of Physics: Conference Series (Vol. 1876, Issue 1). https://doi.org/10.1088/1742-6596/1876/1/012067.

Mehri, M., \& Uplane, M. (2015). Synchronous and asynchronous e-learning styles and academic performance of e-learners. 176, 129-138. https://doi.org/10.1016/j.sbspro.2015.01.453. 
Mourão, S., Luiz, M., \& Barbosa, V. (2018). Ethnotaxomy as a Methodological Tool for Studies of the Ichthyofauna and Its Conservation Implications : A Review. In Ethnozoology (Animals in Our Lives) (Issue 1974). Elsevier Inc. https://doi.org/10.1016/B978-0-12-809913-1.00006-5.

Nouri, J. (2016). The flipped classroom: for active, effective and increased learning - especially for low achievers. International Journal of Educational Technology in Higher Education, 13(1). https://doi.org/10.1186/s41239-016-0032-z.

Pamungkas, A., Subali, B., \& Linuwih, S. (2017). Implementasi model pembelajaran IPA berbasis kearifan lokal untuk meningkatkan kreativitas dan hasil belajar siswa. Jurnal Inovasi Pendidikan IPA, 3(2), 118. https://doi.org/10.21831/jipi.v3i2.14562.

Parmini, N. P. (2021). The Integration of Traditional Balinese Children's Song Lyrics In Indonesian Learning To Instill Moral Education Of Elementary School Students. International Journal of Elementary Education, 4(4), 537-548.

Parwati, N. N. (2015). Pengembangan Model Pembelajaran Pemecahan Masalah Berorientasi Kearifan Lokal Pada Siswa SMP Di Kota Singaraja. JPI (Jurnal Pendidikan Indonesia), 4(2), 612-622. https://doi.org/10.23887/jpi-undiksha.v4i2.6058.

Parwati, N. N. (2018). Local wisdom-oriented problem-solving learning model to improve mathematical problem-solving ability. Journal of Technology and Science Education, 8(4), 310-320. https://doi.org/10.3926/jotse.401.

Pauli, N., Abbott, L. K., Negrete-Yankelevich, S., \& Andrés, P. (2016). Farmers' knowledge and use of soil fauna in agriculture: A worldwide review. Ecology and Society, 21(3). https://doi.org/10.5751/ES08597-210319.

Rabin, J. M., Burgasser, A., Bussey, T. J., Eggers, J., Lo, S. M., Seethaler, S., Stevens, L., \& Weizman, H. (2021). Interdisciplinary conversations in STEM education: can faculty understand each other better than their students do? International Journal of STEM Education, 8(1). https://doi.org/10.1186/s40594-020-00266-9.

Santrock, J. W. (2018). Educational Psychology: Theory and Application To Fitness and Performance, Sixth Edition. In McGraw-Hill Education, 2 Penn Plaza, New York, NY 10121.

Setiawan, B. (2017). The development of local wisdom-based natural science module to improve science literation of students. Jurnal Pendidikan IPA Indonesia, 6(1), 49-54. https://doi.org/10.15294/jpii.v6i1.9595.

Suastra, I. (2017). Developing characters based on local wisdom of bali in teaching physics in senior high school. Jurnal Pendidikan IPA Indonesia, 6(2), 306-312. https://doi.org/10.15294/jpii.v6i2.10681.

Suastra, I. W., Jatmiko, B., Ristiati, N. P., \& Yasmini, L. P. B. (2017). Developing characters based on local wisdom of bali in teaching physics in senior high school. Jurnal Pendidikan IPA Indonesia, 6(2), 306-312. https://doi.org/10.15294/jpii.v6i2.10681.

Sudarmin. (2018). Increasing character value and conservation behavior through integrated ethnoscience chemistry in chemistry learning: A Case Study in the Department of Science Universitas Negeri Semarang. In IOP Conference Series: Materials Science and Engineering (Vol. 349, Issue 1). https://doi.org/10.1088/1757-899X/349/1/012061.

Sugiyono. (2017). Metode Penelitian Kuantitatif, Kualitatif, dan R\&D. Alfabeta.

Suja, I. W. (2017). Integrasi Kearifan Lokal Ke Dalam Kurikulum Ilmu Alamiah Dasar. Jurnal Matematika, Sains, Dan Pembelajarannya, 11(1), 77-93.

Sutajaya, I. M. (2020). Mendidik Masyarakat Melalui Konsep Tri Datu untuk Memertahankan Sikap Kewirausahaan Saat Pandemi COVID 19. Webminar Nasional 2020 "Pengembangan Kompetensi Pendidik Mengimplementasikan Program Merdeka Belajar", 78-88.

Uskov, V. L., \& Howlett, R. J. (2019). Smart Education and e-Learning. Springer Nature Singapore Pte Ltd.

van Alten, D. C. D., Phielix, C., Janssen, J., \& Kester, L. (2020). Self-regulated learning support in flipped learning videos enhances learning outcomes. Computers and Education, 158(July). https://doi.org/10.1016/j.compedu.2020.104000.

Wardani, N. K. T., \& Wiyasa, I. K. N. (2020). Pengaruh Model Pembelajaran Kooperatif Tipe Jigsaw Berbasis Catur Paramitha Terhadap Kompetensi Pengetahuan Matematika. Jurnal Pedagogi Dan Pembelajaran, 3(1), 25. https://doi.org/10.23887/jp2.v3i1.24358.

Weiser, O., Blau, I., \& Eshet-alkalai, Y. (2018). NU SC. In The Internet and Higher Education. Elsevier Inc. https://doi.org/10.1016/j.iheduc.2018.01.001.

Woolfolk, A. (2019). Educational Psychology, 14/e, Global Edition.

$\mathrm{Wu}, \mathrm{P}$. (2018). Development of a visual e-learning system for supporting the semantic organization and utilization of open learning content. Multimedia Tools and Applications, 77(13), 17437-17456. https://doi.org/10.1007/s11042-017-5312-7.

Yudha, I. N., Widiantara, P., Santosa, H., \& Suartaya, K. (2020). Proses Penciptaan Komposisi Karawitan 
Kreasi Baru Paras Paros. 8(April), 1-13.

Zainul, R. (2020). Development of e-Learning Courses for Subjects about "Learn and Learning" with Moodle-based for Prospective Teacher in Indonesia. In Journal of Physics: Conference Series (Vol. 1594, Issue 1). https://doi.org/10.1088/1742-6596/1594/1/012023.

Zambrano R., J., Kirschner, F., Sweller, J., \& Kirschner, P. A. (2019). Effects of prior knowledge on collaborative and individual learning. Learning and Instruction, 63(August 2018), 101214. https://doi.org/10.1016/j.learninstruc.2019.05.011.

Zubaidah, S. (2018). Mengenal 4C: Learning and Inovation Skill untuk Menghadapi Era Revolusi Industri 4.0. 2nd Science Education National Conference. 